\title{
P.A. ROVINSKY AND HIS DISCOVERY OF MONTENEGRO FOR RUSSIAN READERS ${ }^{1}$
}

\section{Abstract:}

The fate of P.A. Rovinsky reads like a story from an adventure novel. He traveled by foot around the Czech and Montenegrin region, was twice expelled from Austria-Hungary, traveled to Siberia, visited China and the United States, was the Director of a colony for juvenile delinquents. He was friends with N.G. Chernyshevsky. But he is most famous for his stay in Montenegro. He was friends with a local Montenegrin prince, inspired great trust and respect among the local population, conducted first archaeological excavations and represented Russia as a diplomat. Most importantly he wrote a multivolume research work on the country, which is still useful today.

Keywords:

P.A. Rovinsky, Montenegro, ethnography, diplomats-scholars.

АнНотация: Н.С. ГУСЕВ. «П.А. РОВИНСКИЙ И ЕГО «ОТКРЫТИЕ» ЧЕРНОГОРИИ ЧИТАТЕЛЯМ РосСии».

В статье рассказывается о судьбе П.А. Ровинского (1831-1916), которая напоминала авантюрный роман. Он обошел пешком чешские и черногорские земли, дважды был выслан за пределы Австро-Венгрии, объехал Сибирь, посетил Китай и США, руководил колонией для малолетних преступников, дружил с Н.Г. Чернышевским. Но в историю он вошел в связи со своим пребыванием в Черногории. Ровинский дружил с местным князем, внушил огромное доверие и уважение к себе у местного населения, впервые провел археологические раскопки, как дипломат представлял Россию, но главное - создал многотомное описание страны, которое не устарело и сейчас.

Ключевые слова:

П.А. Ровинский, Черногория, этнография, дипломаты-ученые.

Davel Apolonovich Rovinsky (1831-1916) was a writer and traveler who 1 traveled half the world, a provincial intellectual with revolutionary views, a famous non-academic Slav of the 19th century, a "dragoman" (interpreter) for the Russian mission in Montenegro, and the founder of Montenegrin archaeology.

Born in the small village of Gusevka (now in the Volgograd region) into a noble family, he studied at the Saratov gymnasium, where he became friends with the future major Slavicist Alexander N. Pypin and the journalist Nikolay G. Chernyshevsky. He then entered Kazan University, where the department of Slavic dialects was headed by the famous academic Viktor I. Grigorovich, who had just returned from a trip to the Slavic countries. Rovinsky often visited his house, used his library and, until the end of his life, emphasized the role this academic

\footnotetext{
1 The work was carried out with the financial support of the RFBR (grant № 18-512-76004).
} 
had played in sparking his interest in the Slavic peoples. In 1852, after graduating from university, Rovinsky was asked to stay to teach in the department of Slavic studies, but four years later he resigned, apparently disappointed in teaching.

In 1860 he set off for Prague, where he familiarized himself with the local social and political life there. Then, donning the costume of a Russian peasant, he began traveling around to Czech villages, for which he was detained by the Austrian police. For political reasons, he was expelled from the Habsburg monarchy. The materials he had accumulated and his impressions then resulted in a series of articles published by Rovinsky in periodicals and historically themed essay. Despite the fact that the latter were mainly based on academic literature, they were innovative in their interpretation of many aspects of Czech history (primarily the Hussite movement) in the revolutionary-populist spirit that was then fashionable in Russia. Rovinsky became a member of the populist Narodnik's circle, "Land and Liberty," and this prevented him from making a new trip to the Slavic regions because of a ban by the Russian authorities. He intended at that time to go to the southern Slav regions in order to study their everyday life, the history of their way of living and advances in education, however, it was only a few years later that he was able to make such a trip.

In 1868 Rovinsky arrived in Belgrade as a correspondent for the newspaper St. Petersburg News and remained in Serbia for a little over a year. His trip was motivated by the fact that in 1867 , after the withdrawal of the Turkish garrisons from the fortresses of the principality, the Balkan Alliance began to take shape to prepare a general uprising against the Turks. "The desires and hopes of all Southern Slavdom were focused on Serbia," is how Rovinsky himself described that period in time. Years later a new crisis erupted in the Balkans, and Rovinsky, as a correspondent for the newspaper Novoye Vremya ("The New Time"), again ended up in Serbia, having spent the summer and autumn of the fateful 1878 there. These two trips and the Slavist's passion for the country resulted in the emergence of an extensive body of texts that shed light on life in Serbia at that time. Rovinsky had a great deal of interest in and sympathy for the Serbs and even romanticized them overly much. However, at the same time he noted with regret that in the history of Serbia "there is almost not a single page of joy: only war, only internecine strife." It thus seemed to him that in this country a "man of eternal war" had emerged. For this reason, according to him, everything in Serbia is "temporary, unsteady, everything is in a state of expectancy of something," and such a situation paralyzes the normal development of the country.

At the same time, Rovinsky started to be drawn to academic work. This resulted in an article about the medieval heretical movement of the Bogomils in the Serbian lands. Here something should be said right away about its shortcomings: a lack of knowledge of this issue at that time, the author's lack of reliable sources and his excessive dedication led to a rather arbitrary interpretation of a number of historical facts. Many of the hypotheses proposed by the scholar did not hold up to scrutiny. 
In 1870 Rovinsky returned to Russia and set off on an ethnographic trip to Siberia, visited Mongolia and China, and in 1874 traveled to America. He then took up the post of director of a colony of juvenile offenders near St. Petersburg, where he began to apply innovative pedagogical methods that were highly praised by his contemporaries, including Fyodor M. Dostoevsky. In 1878, as already mentioned, Rovinsky set off for the Balkans. In addition to Serbia, he spent several months in Bosnia and Herzegovina, newly occupied by Austria-Hungary. In dispatches from there, he introduced Russian readers to the local population, telling about both local Christian Slavs and Muslim Slavs. Due to the incriminating tone of Rovinsky's reporting on Vienna's advance into the Balkans and the repression that ensued, the authorities expelled the journalist. Thus, by a twist of fate, he ended up in Montenegro. Rovinsky did not initially intend to stay there long, but having become interested in the life of the Montenegrins, he lived in the country intermittently from 1879 to 1906.

From 1880 to 1882, Rovinsky traveled around Montenegro on foot, becoming acquainted with its geography and people, collecting folklore material and searching out historical sources in the monasteries and archives of the Montenegrin rulers. He presented the results of his research in the form of a hand-written book to the Department of the Russian Language and Literature of the Russian Academy of Sciences. Two years later Rovinsky's multi-volume work, Montenegro in its Past and Present, was set for publication, but it dragged on for many years. Its volumes were published from 1888 to 1909. Meanwhile, in 1889, the scientist published a book about the Montenegrin ruler and Metropolitan, Petar Negosh (1813-51). A grand-nephew of this prominent Montenegrin ruler and poet, Prince Nikola, suggested that Rovinsky begin an archaeological study of the remains of the Roman city of Dioclea. For several years, in accordance with the scientific methods of the time, Rovinsky studied the ancient city buildings he discovered and the graffiti on their walls.

From 1898 to 1902 the scholar lived in his native village, preparing for publication the next volumes of his work, Montenegro in its Past and Present. He then returned to the country that had become his home as a dragoman of the Russian mission, in which status he remained until 1906. Thanks to his connections and fame, he was able to assess the reality of the situation there, to influence the Montenegrin monarch and to help Russian citizens on their scientific and business trips around the country. One of the Russian travelers who visited Montenegro at that time left a beautiful verbal portrait of the subject of this article: "Imagine a man in a well-worn gray suit and a Montenegrin kapitsa (hat), of medium height and lean. Gray hair densely covers his wrinkled face with a frozen expression of infinite kindness and gentleness. On his nose are glasses in a simple frame, through which inquisitive eyes gaze with sable overhanging eyebrows. His wrinkled forehead is high and reflects a remarkable mind as well as an indomitable energy. Imagine a person of extraordinary modesty and incorruptible candour. This will be P. A. "Rovinsky, whose name is pronounced with 
respect in all the Slavic lands, his book is a four-volume monumental work, the significance and value of which can be equated with Karamzin's History of the Russian State."

In this "monumental work" the author divided Montenegrin history into three periods. Into the first, he placed the Middle Ages to the beginning of the sixteenth century, when these lands were part of a Serbian state and were indistinguishable from the rest of Serbia. He called the second period theocratic, setting its chronological boundaries from 1516 to 1851. At that time the country was not a secular state but a theocratic state, in which all functions of state were concentrated in the hands of the church. According to Rovinsky, it was precisely this form of government that best suited Montenegro's tribal structure. His assessment was negative of the changes that took place after the country was proclaimed a principality: the people had turned into an army, which caused an economic collapse and made the political system harsh.

The main virtue of his book, which has not lost its academic significance today, is its ethnographic material. The scholar collected it a long period of time and with care, communicating with the peasants and delving into their everyday lives. The relations of the Russian Slavicist with the local population are perfectly encapsulated in the following fact: the local residents trusted him so much that they invited him to be an arbitrator in resolving their internal disputes and lawsuits. Rovinsky had a great deal of sympathy for the Montenegrins, portraying them with a certain share of romanticism. However, at the same time, he did not conceal their negative traits: the neglect of their work by men who preferred to be warriors, shifting household concerns onto the shoulders of women, the observance of the custom of blood feuds, etc.

After returning from Montenegro and settling in St. Petersburg, Rovinsky continued his work for some time, but gradually moved away from journalism and became less and less of a public figure. At fault was probably the scholar's advanced age. Nevertheless, he remained the foremost specialist on Montenegro. Officer N. P. Mamontov, who visited Montenegro in 1909 and wrote a book about it, considered it necessary to give it to Rovinsky to review. In a cover letter, he wrote that in Montenegro he had met Rovinsky's acquaintances everywhere, and that Rovinsky's name was often heard coming from their lips, always "pronounced with a feeling of utmost love and respect for you." The Balkan wars of 1912-13, which completed the process of liberating the Balkans from the power of the Ottoman Empire, gave rise to Rovinsky's plans for new books and works, but he apparently lacked the strength to complete them. Only a few handwritten drafts remain.

At the end of 1915, Pavel Apollonovich fell gravely ill, dying in January of the following year. He was buried on the Literary Bridges of the Volkov's Cemetery in St. Petersburg. The deceased was personally buried (which is very symbolic) by the Montenegrin hieromonk Mordary, who, in his eulogy, told the story of how as a young man, he had met the scholar in Montenegro. 
Rovinsky was the foremost expert on the Balkans of the early twentieth century. He was able to understand the local people not from books, but as a result of communicating with living people. Many of his conclusions in the field of history were eventually refuted by scholarship, but the ethnographic material he collected retains its significance to this day. Thanks to the fact that Rovinsky covered the countries of interest to him on foot, he succeeded in penetrating the essence of the mentality of the inhabitants of the Balkans. No wonder almost half a century before the Balkan Wars, in a letter to a childhood friend, Alexander Pypin, he expressed a disappointing but accurate prophecy: "The southern Slavs will defeat the Turks, but they will fight among themselves."

Translated by Igor Kaliganov

\section{BIBLIOGRAPHY}

Khlebnikova V.B. Pavel Apollonovich Rovinskii v Chernogorii // Slavianovedenie. 1987. N 2.

Khlebnikova V.B. Rovinskii kak issledovatel' Chernogorii. Diss. ... kand. ist. nauk. Moscow, 1986.

Lapteva L.P. Istoriia slavianovedeniia v Rossii v kontse XIX — pervoi treti XX vv. Moscow, 2012.

Pakhomova LIu. P.A. Rovinskii o musul'manskom obshchestve na nachal'nom ètape avstro-vengerskoi okkupatsii Bosnii i Gertsegoviny // Slavianskii mir v tret'em tysiacheletii. Etnicheskie, konfessional'nye, sotsiokul'turnye komponenty identichnosti narodov Tsentral'noi, Vostochnoi i Iugo-Vostochnoi Evropy. Moscow, 2017.

\section{ILLUSTRATIONS}

1. A portrait of P.A. Rovinsky.

2. A memorial plagues to the scholar in his native village of Gusevka.

3. Photograph of P.A. Rovinsky in a Montenegrin costume.

4. P.A. Rovinsky's book "Montenegro in its past and present."

5. View of Dioclea, the ancient city in the Balkans (Montenegro), where P.A. Rovinsky made his first archaeological excavations.

6. The journal in which P.A. Rovinsky published his numerous articles on the Balkans and the Slavic movement. 